Gökkuş, ì. ve Akyol, H. (2020). Sesbilgisel farkındalık öğretiminin, erken okuryazarlık becerilerinin gelişimine etkisi. Ana Dili Eğitimi Dergisi, 8(2), 368-385.

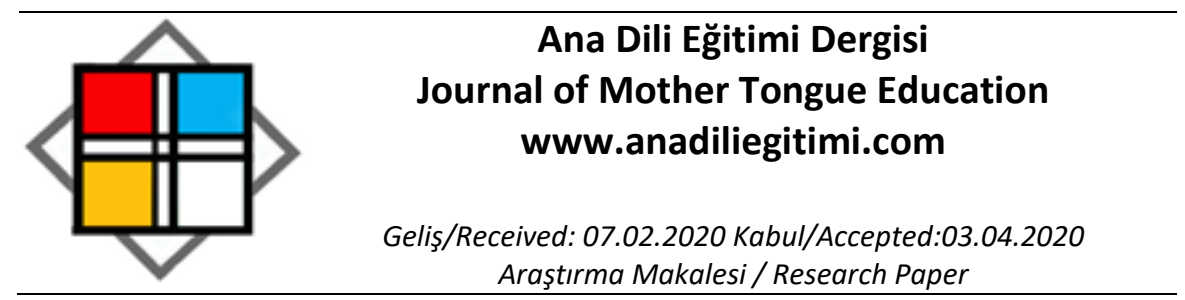

\title{
Sesbilgisel Farkındalık Öğretiminin, Erken Okuryazarlık Becerilerinin Gelişimine Etkisi *
}

\author{
iclal GÖKKUŞ \\ Hayati $A K Y O L^{* * *}$
}

Öz

Bu araştırmanın amacı, sesbilgisel farkındalık öğretiminin, ilkokul birinci sınıf öğrencilerinin erken okuryazarlık becerilerinin (sesbilgisel farkındalık, yazı farkındalığı ve kelime bilgisi) gelişimine olan etkisini belirlemektir. Ön test- son test kontrol gruplu yarı deneysel desende planlanan araştırma, 24 deney; 23 kontrol grubu olmak üzere 47 ilkokul birinci sınıf öğrencisi ile yapılmıştır. Çalışma grubundaki öğrencilere, Ses Bilgisi Farkındalık Ölçeği, Fonolojik Farkındalık Ölçeği, Yazı Farkındalığını Değerlendirme Kontrol Listesi ve Peabody Resim Kelime Testi deneysel işlem öncesinde ve sonrasında uygulanmıştır. Deney grubundaki çocuklara, sesbilgisel farkındalık öğretimi, sekiz hafta boyunca uygulanarak deneysel işlem gerçekleştirilmiştir. Yapılan analizler sonucunda, uygulanan sesbilgisel farkındalık öğretiminin, erken okuryazarlık becerilerinin gelişiminde yüksek düzeyde bir etkiye sahip olduğu belirlenmiştir.

Anahtar Kelimeler: Sesbilgisel farkındalık öğretimi, erken okuryazarlık, ilkokul birinci sınıf

\section{The Effect of Phonological Awareness Training on the Development of Early Literacy Skills}

\begin{abstract}
The purpose of this study was to determine the effect of the phonological awareness training on the development of early literacy skills (phonogical awareness, print awareness and vocabulary knowledge) of the first grade elementary school students. The research, which was planned as pretest-posttest quasi experimental design with a control group, was conducted with 47 the first grade elementary school students including 24 experimental and 23 control groups. Phonetic Awareness Scale, Phonological Awareness Scale, Writing Awareness Checklist and Peabody Picture Vocabulary Test were applied to the students in the study group before and after the experimental process. The experimental process was carried out by applying activities in the phonological awareness training to the children in the experimental group for eight weeks. It was been determined that the phonological awareness training has a high level of influence in the development of early literacy.
\end{abstract}

Keywords: Phonological awareness training, early literacy, first grade elementary school

\section{Giriş}

Sesbilgisel farkındalık, okuma üzerinde önemli etkisi olan sözel bir dil becerisidir. Sözel dilin farklı yöntemler kullanarak (kelimelerden seslere ulaşma, başlangıç ve son sesi bölme, kelimenin tek tek bütün seslerini ayırma, sesleri atma, ekleme ve yeni kelimeler oluşturma gibi) daha küçük birimlere ayrılacağının farkında olmak (Chard ve Dickson, 1999), söylenenleri anlamından bağımsız, tek tek ses

\footnotetext{
*Bu makale, 2016 yılında İclal Gökkuş'un Hayati Akyol danışmanlığında yürüttüğü "Erken Okuryazarlık Becerilerinin Gelişiminde Ses Bilgisi Farkındalık Programının Etkisi" adlı doktora tezinin bir kısmında üretilmiştir. ** Dr. Öğr. Üyesi, Sivas Cumhuriyet Üniversitesi, Eğitim Fakültesi, Temel Eğitim Bölümü, Sınıf Eğitimi ABD, Sivas, TÜRKIYE dagdevireniclal@gmail.com, ORCID: 0000-0002-2721-9892

*** Prof.Dr., Gazi Üniversitesi, Eğitim Fakültesi, Temel Eğitim Bölümü, Sınıf Eğitimi ABD, Ankara, TÜRKiYE hakyol@gazi.edu.tr, ORCID: 0000-0002-4450-2374
} 
dizisi olarak algılayabilmek ve sesbirimleri etkili kullanabilmek (Aktan, 1996:92) olarak tanımlanmaktadır. Sesbilgisel farkındalık, doğrudan öğretimle edinilen bir beceridir ve özenle planlanan sistemli bir öğretimi gerektirmektedir. Türkçe gibi alfabetik yazı dillerinde kelimeler genel olarak sesbirim düzeyinde yazıya aktarılmakta; sesler ve harfler birebir eşleşmektedir. Türkçe gibi sesharf ilişkileri şeffaf olan dillerde kelimelerin yazılı olarak nasıl temsil edildiğini öğrenmek için sesbilgisel farkındalık becerilerinin kazanılması gerekmektedir. Bundan dolayı Türkçenin dil yapısına uygun, sesbilgisel farkındalık becerilerini geliştiren öğretim programlarının hazırlanması önem taşımaktadır.

Türkiye'deki sesbilgisel farkındalığa (fonolojik farkındalık) ilişkin alanyazın incelendiğinde; yapılan çaılışmaların, tarama (Akbey, 2016; Aktan, 1996; Balcı, 2006; Demirtaş, 2017; Erdoğan, 2009; Erkan Süel, 2011; İslamoğlu, 2019; Karakelle, 2004; Karaman, 2006; Sürgen, 2019; Turan ve Akoğlu, 2014;) boylamsal tarama (Güldenoğlu, Kargın ve Ergül, 2016; Soğancı, 2017), deneysel (Akdal, 2018; Aktan Kerem, 2001; Akoğlu ve Turan, 2012; Bayraktar, 2013; Dinler, 2018; Gül, 2006; Parpucu,2016; Topalca, 2019; Turan ve Akoğlu, 2011; Yücel, 2009), ölçme aracı geliştirme (Büyüktaşkapu, 2012; Kazanoğlu, 2017; Sarı, 2012), derleme (Sayar ve Turan, 2012; Turan ve Gül, 2008) araştırmaları olduğu tespit edilmiştir. Türkiye'de sesbilgisel farkındalık becerilerine yönelik hazırlanan öğretim programlarının etkisini inceleyen deneysel araştırmaların sınırlı sayıda olduğu ve bu araştırmalarda da verilen sesbilgisel farkındalık öğretiminin, sesbilgisel farkındalık, artikülasyon, işitsel ayırt etme, alıcı dil, harf tanıma ve okuma becerisi üzerine etkisinin incelendiği görülmüştür. Bu deneysel araştırmalarda, sesbilgisel farkındalık öğretiminin, erken okuryazarlık becerilerinden ya sadece sesbilgisel farkındalık becerilerine (Akdal, 2018; Dinler, 2018; Turan ve Akoğlu, 2011) ya da sesbilgisel farkındalık-alıcı dil becerilerine (Akoğlu ve Turan, 2012; Gül, 2006; Yücel, 2009) veya sesbilgisel farkındalık-harf tanıma bilgisine (Parpucu, 2016) etkisinin incelendiği, bunlarında okul öncesi ve özel eğitim gerektiren öğrencilerle gerçekleştirildiği belirlenmiştir.

Sesbilgisel farkındalık, en önemli erken okuryazarlık becerilerinden biridir. Erken okuryazarlık becerileri okuma becerileri için öncü beceriler olduğu gibi okuma becerilerinin gelişim sürecinin de doğal bir aşamasıdır. Erken okuryazarlık becerileri, erken çocukluk döneminde bir sıra halinde değil, birlikte ve birbirinden etkilenerek gelişim göstermektedir. Bu yüzden hazırlanan sesbilgisel farkındalık öğretim programlarının, sadece sesbilgisel farkındalık becerilerini değil diğer erken okuryazarlık becerilerini (yazı farkındalığı, kelime bilgisi vd.) de geliştirmesi beklenmelidir. Bununla birlikte, sesbilgisel farkındalık becerilerinin okuma becerilerine etkisi sadece okul öncesi dönemde değil üst sınıflarda da devam etmektedir (Chard ve Dickson, 1999). Çocukların bilişsel-dilbilim becerileri altı yaşında olgunlaşamaya başladığından ve alfabetik yazıyı okumayı öğrenmeye birinci sınıfta başlandığından, birinci sınıfta sesbilgisel farkındalık becerisinin gelişimi önem taşımaktadır (Bentin, Hammer ve Cahan, 1991: 271).

Sonuç olarak, Türkiye'deki alanyazın incelendiğinde, normal gelişim gösteren ilkokul birinci sınıf öğrencilerine uygulanan sesbilgisel farkındalık öğretim programlarının, erken okuryazarlık becerilerine etkisini inceleyen bir çalışmanın olmadığı belirlenmiştir. Bu çalışmada, normal gelişim gösteren ilkokul birinci sınıf öğrencilerine yönelik hazırlanan sesbilgisel farkındalık öğretim programının (Ses Bilgisi Farkındalık Programı-SBFP), erken okuryazarlık becerilerinden, sesbilgisel farkındalık becerilerinin, yazı farkındalığı becerilerinin ve kelime bilgisinin gelişimine olan etkisi incelenmiştir. Bu amaç kapsamında aşağıdaki araştırma problemlerine cevap aranmıştır:

1. Kontrol grubundaki öğrencilerin, sesbilgisel farkındalık becerilerini, yazı farkındalığı becerilerini ve kelime bilgisini ölçmeye yönelik kullanılan testlerden aldıkları ön test ve son test puanları arasında anlamlı farklılık var mıdır?

2. Deney grubundaki öğrencilerin sesbilgisel farkındalık becerilerini, yazı farkındalığı becerilerini ve kelime bilgisini ölçmeye yönelik kullanılan testlerden aldıkları ön test ve son test puanları arasında anlamlı farklılık var mıdır?

3. Hazırlanan "Ses Bilgisi Farkındalık Programı (SBFP)" uygulandıktan sonra deney ve kontrol grubundaki öğrencilerin sesbilgisel farkındalık becerilerini, yazı farkındalığı becerilerini ve kelime bilgisini ölçmeye yönelik kullanılan testlerden aldıkları son test puanları arasında anlamlı bir fark var mıdır? 


\section{Araştırmanın Modeli}

\section{Yöntem}

Bu araştırma, hazırlanan sesbilgisel farkındalık öğretiminin, normal gelişim gösteren ilkokul birinci sınıf öğrencilerinin erken okuryazarlık becerilerinin gelişimi üzerine etkisini belirlemeye yönelik deneysel bir çalışmadır. Araştırma, deneysel desenlerden ön test-son test kontrol gruplu yarı deneysel desende planlanmıştır.

\section{Çalışma Grubu}

Bu araştırma, seçkisiz atamayı içermeyen yarı deneysel desen olduğu için örneklem seçimine gidilmemiş, yerine çalışma grubu belirlenmiştir. Çalışma grubunun belirlenmesinde, çok aşamalı bir yol izlendiğinden, çok aşamalı örnekleme tekniği kullanılarak çalışma grubu belirlenmiştir (Cohen, Manion ve Morrison, 2000).

Bu doğrultuda öncelikle araştırmanın yürütüleceği okullar amaçlı örnekleme yöntemi ile kararlaştırılmıştır. Türkiye İstatistik Kurumundan alınan bilgiler doğrultusunda orta sosyo-ekonomik düzeyde olan okullar belirlenmiştir. Milli Eğitim Müdürlüğünden alınan resmi izinler doğrultusunda belirlenen okullara gidilmiş, okul yönetimi ve birinci sınıf öğretmenleri ile görüşülmüştür. Okulların belirlenmesinde, araştırmanın yürütülmesine gönüllü olan ve araştırmayı destekleyen okul yönetimi dikkate alınmıştır. Bununla birlikte araştırmanın yürütüleceği dersliklerin çalışmaya uygunluğu da göz önünde bulundurulmuştur. Bu şartları sağlayan orta sosyo-ekonomik düzeydeki okullar uygun örneklem yöntemi ile belirlenmiştir. Daha sonra belirlenen bu okullar arasından tesadüfi örnekleme yöntemi kullanılarak seçilen A ilkokulu ile çalışılmaya karar verilmiştir. Araştırmaya katılmaya gönüllü olan sınıf öğretmenlerine ait beş birinci sınıf şubesine ölçüm araçları uygulanmış ve yapılan ölçümler sonucunda denk olan şubeler içinden, cinsiyetleri aynı, yaşları ve öğretmenlik deneyimleri birbirine yakın olan öğretmenlere ait iki birinci sınıf şubesi araştırma kapsamına alınmıştır. Daha sonra bu şubeler, deney grubu ve kontrol grubu olarak yansız atanmıştır.

Araştırmanın çalışma grubunu, 2014-2015 eğitim-öğretim yılı güz yarıyılında Sivas il merkezinde bir devlet ilkokulunun iki şubesinde öğrenim gören toplam 47 birinci sınıf öğrencisi oluşturmuştur. Çalışma grubunda yer alan birinci sınıf öğrencilerin 24'ü deney, 23'ü kontrol grubunda yer almıştır.

Grupların, deneysel işlemden önce, sesbilgisel farkındalık becerileri, yazı farkındalığı becerileri ve kelime bilgisi açısından denk olduğu göstermek amacıyla, grupların sesbilgisel farkındalığa, yazı farkındalığına ve kelime bilgisine ait ön test puanları karşılaştırılmıştır. Araştırmada grupların ön test puanlarını karşılaştırmak için, 1. Ses Bilgisi Farkındalık Ölçeği (SBFÖ), 2. Fonolojik Farkındalık Ölçeği (FFÖ), 3. Yazı Farkındalığını Değerlendirme Kontrol Listesi (YFDL), 4. Peabody Resim Kelime Testi'ne (PRKT) ait ön test puanlarına ilişkin bağımsız gruplar t testi yapılmıştır. Deney ve kontrol grubunun SBFÖ, FFÖ, YFDL ve PRKT'ne ait ön test puanlarına ilişkin analiz sonuçlarına Tablo 1'de yer verilmiştir.

Tablo 1.

Deney ve kontrol grubunun SBFÖ, FFÖ, YFDL ve PRKT'ne ait ön test puanlarına ilişkin analiz sonuçları

\begin{tabular}{|c|c|c|c|c|c|c|c|c|c|}
\hline \multicolumn{10}{|c|}{ Bağımsız Gruplar t-Testi Sonuçları } \\
\hline \multirow{2}{*}{ Ölçüt } & \multirow{2}{*}{ Grup } & \multirow{2}{*}{$\mathrm{N}$} & \multirow{2}{*}{ A.O. } & \multirow{2}{*}{ S.S. } & \multicolumn{2}{|c|}{ Levene Testi } & \multirow{2}{*}{$\mathrm{t}$} & \multirow{2}{*}{ sd } & \multirow{2}{*}{$p$} \\
\hline & & & & & $\mathrm{F}$ & $p$ & & & \\
\hline SBFÖ & Deney & 24 & 19.88 & 10.66 & .01 & .902 & .27 & 45 & .786 \\
\hline (Sesbilgisel Farkındalık) & Kontrol & 23 & 20.71 & 9.97 & & & & & \\
\hline FFÖ & Deney & 24 & 6.20 & 4.08 & .01 & .892 & .40 & 45 & .685 \\
\hline (Sesbilgisel Farkındalık) & Kontrol & 23 & 6.69 & 4.08 & & & & & \\
\hline YFDL & Deney & 24 & 6.58 & 2.99 & .07 & .791 & -.54 & 45 & .590 \\
\hline (Yazı Farkındalığı) & Kontrol & 23 & 7.08 & 3.36 & & & & & \\
\hline PRKT & Deney & 24 & 6.72 & 1.37 & .05 & .821 & -.50 & 45 & .619 \\
\hline (Kelime Bilgisi) & Kontrol & 23 & 6.91 & 1.24 & & & & & \\
\hline
\end{tabular}

$* p<.05$ 
Tablo 1 incelendiğinde, deney ve kontrol grubundaki öğrencilerinin, SBFÖ [t(45)=.27; $p=.786]$, FFÖ [t(45)=.40; $\mathrm{p}=.685$ ], YFDL [t(45)=-.54; $\mathrm{p}=.590]$ ve PRKT [t(45)=-.50; $\mathrm{p}=.619]$ ön test puan ortalamaları arasında istatistiksel açıdan anlamlı bir farklılık olmadığı belirlenmiştir. Bu durum grupların erken okuryazarlık becerilerinden, "sesbilgisel farkındalık, yazı farkındalığı ve kelime bilgisi" açısından denk olduğu şeklinde yorumlanabilir.

\section{Veri Toplama Araçları}

Araştırmada, deneysel işlem öncesi ve sonrasında gruplara ön test ve son test olarak sesbilgisel farkındalık becerilerini ölçmek için, "Ses Bilgisi Farkındalık Ölçeği-SBFÖ (Gökkuş, 2016) ve Fonolojik Farkındalık Ölçeği-FFÖ (Yangın, Erdoğan ve Erdoğan, 2008)"; yazı farkındalığını becerilerini ölçmek için, "Yazı Farkındalığını Değerlendirme Kontrol Listesi-YFDKL (Şimşek, 2011)" ve kelime bilgisini ölçmek içinde, “Peabody Resim Kelime Testi-PRKT (Katz, Önen, Demir, Uzlukaya ve Uludağ, 1974)" veri toplama araçları olarak kullanılımıştır.

\section{Ses Bilgisi Farkındalık Ölçeği (SBFÖ)}

Ses Bilgisel Farkındalık Ölçeği, 5;6-9;11 aylık (5 yaş 6 ay-9 yaş 11 ay) çocukların sesbilgisel farkındalık becerilerinden, kelime farkındalığı (Kelimeleri birleştirerek birleşik kelime oluşturma, birleşik kelimeleri ayırma), hece farkındalığı (hece birleştirme, hece ayırma), uyak farkındalığı (uyaklı kelimeyi bulma-uyak üretme), sesbirim farkındalığı (sesleri birleştirme-sesleri ayırma, ilk sesi atma-son sesi atma, ilk sesi değiştirme-son sesi değiştirme) becerilerini değerlendirmek amacı ile Gökkuş (2016) tarafından hazırlanmıştır. Sesbilgisel Farkındalık Ölçeği, "kelime, hece, uyak ve sesbirim" olmak üzere dört bölümden, dokuz alt testten ve 60 maddeden oluşmaktadır. Her doğru cevap için test kayıt formuna bir (1) puan her yanlış cevap için sıfır (0) puan işlenmiştir. Ölçekten alınabilecek en yüksek puan 60'tır. SBFÖ için hesaplanan güvenirlik katsayıları "KR-20=.97"; kelime farkındalığı bileşeni için hesaplanan güvenirlik katsayıları "KR-20=.89;", hece farkındalığı bileşeni için hesaplanan güvenirlik katsayıları "KR-20=.86", uyak farkındalığı bileşeni için hesaplanan güvenirlik katsayıları "KR-20=.78" ve sesbirim farkındalığı bileşeni için hesaplanan güvenirlik katsayıları "KR-20=.93" olarak hesaplanmıştır.

\section{Fonolojik Farkındalık Ölçeği (FFÖ)}

Birinci sınıfa yeni başlayacak olan öğrencilerin sesbilgisel farkındalık seviyelerini ölçmek amacıyla Yangın, Erdoğan ve Erdoğan (2008) tarafından geliştirilmiştir. Öğrencilerin sesbilgisel farkındalık seviyelerini; "cümlelerin kelimelerden meydana geldiğinin, kelimelerin uyaklı olabileceğinin, kelimelerin aynı sesle başlayabileceğinin, kelimelerin aynı sesle bitebileceğinin, kelimelerin hecelerden meydana geldiğinin farkında olma" becerilerine göre belirlenmiştir. Fonolojik farkındalık ölçeği, bu becerileri temel alan beş alt boyuttan ve toplam otuz beş maddeden oluşmaktadır. Her doğru cevap için test kayıt formuna bir (1) puan her yanlış cevap için sıfır (0) puan işlenmiştir. Ölçekten alınabilecek en yüksek puan 35'tir. Ölçek 152 çocuk üzerinde uygulanmıştır. Ölçeğin KR-20 güvenirlik katsayısı “.74” olarak bulunmuştur (Erdoğan, 2009: 51).

\section{Yazı Farkındalığını Değerlendirme Kontrol Listesi (YFDKL)}

Okul öncesi dönemdeki çocukların, kitap kavramları, yazının işlevi, yazının şekli, yazının yönü, yazıyla ilgili cümle, kelime, harf gibi kavramlara ilişkin bilgi düzeylerini değerlendirmek amacı ile Şimşek (2011) tarafından hazırlanmıştır. "Renkli Tüy" ve "Ömer Pasta Yapıyor" isimli iki hikâye kitabı kullanılarak, 17 maddeden oluşan liste çocuklara uygulanmıştır. Her doğru cevap için test kayıt formuna bir (1) puan her yanlış cevap için sıfır (0) puan işlenmiştir. Kontrol listesinden alınabilecek en yüksek puan 17'dir. Ölçeğin KR-20 güvenirlik katsayısı “.72" bulunmuştur.

\section{Türkçe Konuşan Çocuklar için Peabody Resim Kelime Testi/Form-B (PRKT)}

Aslı, İngilizce 'Peabody Picture Vocabulary Test' olarak L.M. Dunn tarafından geliştirilen testin Türkçeye uyarlanması J. Katz; F. Önen; N. Demir; A. Uzlukaya ve P. Uludağ (1974) tarafından yapılmıştır. Test, Türkçe formda, Peabody Resim Kelime Testi olarak isimlendirilmiştir. Peabody Resim Kelime Testi, 
kelime bilgisinin gelişimini ölçmek amacıyla geliştirilen bir performans testidir. 2-12 yaş arası çocuklara bireysel olarak uygulanır. PRKT, üzerinde dört resim bulunan 100 adet karttan oluşmaktadır. Çocuklardan her kart gösterildiğinde, söylenen kelimeyi temsil eden resmi göstermesi istenmekte; son sekiz sorudan altı tanesine yanlıs cevap verilinceye kadar teste devam edilmektedir. En son bilinen kelimenin sıra numarasından, o kelimeye kadar yapılan yanlışlar çıkartılarak ham puan bulunmaktadır. Ham puanlar norm tablosuna göre yorumlanarak çocuğun alıcı dil yaşı belirlenmektedir.

\section{İşlem / Verilerin Toplanması}

\section{Deneysel İşlem Öncesi Yapılan İşlemler}

Bu süreçte, (1) "Ses Bilgisi Farkındalık Programı" hazırlanmış, (2) araştırmada kullanılacak veri toplama araçları hazırlanmış ve geliştirilmiş, (3) uygulanacak ölçekler için uygulayıcı güvenirliği sağlanmış (4) deneysel uygulama için çalışma grubu belirlenmiştir. Veri toplama araçlarının hazırlanması ve geliştirmesine "veri toplama araçları" kısmında, uygulayıcı güvenirliğine "geçerlik ve güvenirlik" kısmında, çalışma grubunun belirlenmesine "çalışma grubu" kısmında yer verildiğinden, bu kısımda sadece Ses Bilgisel Farkındalık Programının hazırlanması hakkında bilgi sunulmuştur.

\section{Ses Bilgisi Farkındalık Programının Hazırlanması.}

Öğretim programının hazırlanmasında, Adams, Foorman, Lundberg ve Beeler (2002) tarafından hazırlanan sesbilgisel farkındalık öğretim programından yararlanıımıştır. Bu programda yer alan oyun ve etkinlikler temel alınarak Türkçe'nin dil yapısına uygun, birinci sınıf öğrencilerinin sesbilgisel farkındalık becerilerini geliştirmeye yönelik oyun ve etkinlikler hazırlanmıştır. Öncelikle oyun ve etkinlikler Türkçe'ye çevrilmiştir. Daha sonra etkinliklerde kullanılacak tekerlemelerin, kelimelerin, kavramların, resimlerin ve nesnelerin listesi oluşturulmuştur. Bu liste hazırlanırken birinci sınıf öğrencilerine yönelik yapılan kelime hazinesine çalışmaları, öğretim programları, kelime tanıma testleri, ders kitapları ve çocuk edebiyatı kitapları incelenmiştir. Bu listedeki tekerlemeler, kelimeler, kavramlar, nesneler ve resimler; etkinliklerin özüne uygun olarak kullanılmıştır. Sesbilgisel farkındalık becerilerinin gelişim sırasına göre yer alan etkinlerden faydalanılarak oturumlar oluşturulmuştur. Sekiz hafta boyunca, haftada beş gün olmak üzere; dinleme- uyak- kelime-hece- ilk ses ve son ses- sesbirimses- harf eşleştirme" şeklinde yedi aşama altında 40 oturum planlanmıştır. Bu yedi aşama ve oturumlar kolaydan zora doğu sıralanmıştır. Her biri 15-30 dakika olan oturumlarda bir veya iki etkinlik yapılmıştır. Ses Bilgisi Farkındalık Programı'nın her aşamasında yapan etkinlik türlerine Tablo 2'de yer verilmiştir. Her bir aşama sonunda, o aşamada çalışılan beceri ile ilgili çalışma yaprakları hazırlanmıştır. Hazırlanan oturumlar uzman görüşüne sunulmuş, gerekli düzeltmeler yapıldıktan sonra yaklaşık iki haftalık bir sürede, hazırlanan programın pilot uygulaması yapılmıştır.

Tablo 2.

Ses Bilgisi Farkındalık Programı'nın aşamalarında yapılan etkinlikler türleri

\begin{tabular}{|c|c|}
\hline Aşamalar & Yapılan Etkinlikler \\
\hline 1-Dinleme & $\begin{array}{ll}\checkmark & \text { Doğada, çeşitli varlıklara ait duydukları sesleri ayırt etme } \\
\checkmark & \text { Doğada, çeşitli varlıklara ait duydukları sesleri sırası ile ifade etme } \\
\checkmark & \text { Sesin kaynağının yerini belirleme } \\
\checkmark & \text { Dikkatli dinleme }\end{array}$ \\
\hline 2-Uyak Farkındalığı & $\begin{array}{ll}\checkmark & \text { Uyaklı kelimeleri fark etme } \\
\checkmark & \text { Uyaklı kelimeleri ayırt etme } \\
\checkmark & \text { Uyaklı kelimeler üretme }\end{array}$ \\
\hline 3-Kelime Farkındalığı & $\begin{array}{ll}\checkmark & \text { Söylenen şeyin cümle olup olmadığını ayırt etme } \\
\checkmark & \text { Cümlemin bir dizi kelimeden oluştuğunu anlama } \\
\checkmark & \text { Kelimenin uzunluğunu karılaştırma } \\
\checkmark & \text { Birleşik kelimeleri fark etme }\end{array}$ \\
\hline 4-Hece Farkındalığı & $\begin{array}{ll}\checkmark & \text { Kelimeleri hecelere ayırma } \\
\checkmark & \text { Heceleri birleştirme }\end{array}$ \\
\hline
\end{tabular}




\begin{tabular}{|l|cl|}
\hline 5-illk-Son Ses Farkındalığı & $\checkmark$ & Kelimelerin ilk sesini fark etme \\
& $\checkmark$ & Kelimeden ilk sesi çıkarma \\
& $\checkmark$ & Kelimenin başlangıcına ses ekleme \\
& $\checkmark$ & Kelimelerin son sesini fark etme \\
\hline 6-Sesbirim Farkındalı̆̆ı & $\checkmark$ & Kelimeleri seslerine ayırma \\
& $\checkmark$ & Sesleri bir araya getirerek kelime oluşturma \\
& $\checkmark$ & Kelimeden ses atma \\
& $\checkmark$ & Kelimeye ses ekleme \\
\hline 7-Ses-Harf Eşleştirme & $\checkmark$ & Harf ve ses arasındaki ilişkiyi fark etme \\
& $\checkmark$ & Kelimeye yeni bir harf ekleme \\
& $\checkmark$ & Kelimedeki harfi başka bir harfle değiştirme \\
\hline
\end{tabular}

\section{Deneysel işlem Sürecinde Uygulanan işlemler}

Araştırmanın deneysel işlemi, 12 haftalık bir süreçte gerçekleştirilmiştir. Ilk iki hafta ve son iki hafta veri toplama araçlarının uygulanmasına ayrılmış geriye kalan sekiz hafta boyunca da deneysel işlem yürütülmüştür

Deney grubunda yer alan öğrencilerle yürütülen işlemler, ön testlerin uygulanması ile başlamıştır. Ön testlerin uygulanmasından sonra, deney grubunda öğretmen tarafından "ilkokul Türkçe Dersi Öğretim Programı" kapsamında, ders kitabı ve öğrenci çalışma kitaplarında yer aldığı biçimiyle Türkçe dersini yürütürken, öğretmenin uygun gördüğü ders saatlerinde de araştırmacı tarafından 8 hafta boyunca hazırlanan "Ses Bilgisi Farkındalık Programı-(SBFP)" uygulanmıştır. SBFP dinleme aşamasında (5), uyak aşamasında (6), cümle-kelime aşamasında (5), hece aşamasında (4), ilk ses- son ses aşamasında (6), ses birim aşamasında (7) ve ses harf eşleştirme aşamasında (7) olmak üzere toplam 40 oturumda uygulanmıştır. Bu aşamalar zorluk derecelerine göre sıralanmış ve bir aşamadaki oturumlar tamamlanmadan diğer aşamalara geçilmemiştir. Her oturumda 15-30 dakika süren en fazla iki etkinliğe yer verilmiştir. Oturumlar hazırlanan günlük planlar doğrultusunda araştırmacı tarafından yürütülmüştür. Bu oturumlarda yapılan etkinliklerden bir tanesine aşağıda yer verilmiştir:

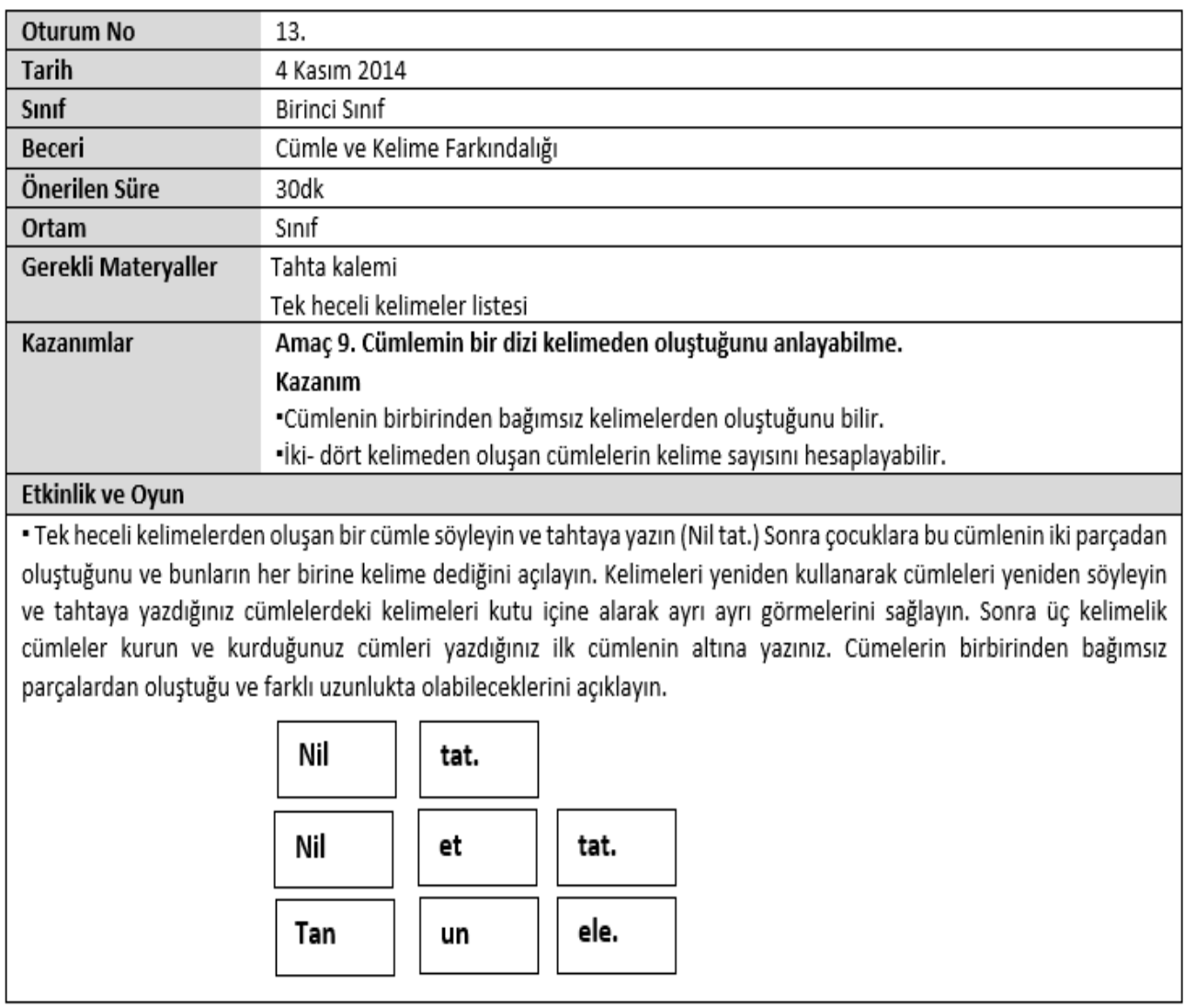




\begin{tabular}{|c|c|c|}
\hline \multicolumn{3}{|l|}{$\begin{array}{l}\text { - Cümledek } \\
\text { olduğundan } \\
\text { edin. Daha } \\
\text { alındıktan s } \\
\text { gösterin. }\end{array}$} \\
\hline \multirow{12}{*}{$\begin{array}{l}\text { - Cümlede } \\
\text { olduğunda } \\
\text { edin. Daha } \\
\text { alındıktan } \\
\text { gösterin. }\end{array}$} & $\begin{array}{l}\text { Tek heceli kelimelerden } \\
\text { oluşan cümleler }\end{array}$ & $\begin{array}{l}\text { Tek heceli kelimeler oluşan } \\
\text { cümlelerle çalışıldıktan sonra } \\
\text { aşağıdaki cümleler yapılabilir. }\end{array}$ \\
\hline & Mert gel. & Talat un ele. \\
\hline & Cem tuz at. & Mete ete tuz at. \\
\hline & Nur ip al. & Nil süt al. \\
\hline & Can tut. & Ata iri taneli nar al. \\
\hline & Nil su iç. & Talat eval. \\
\hline & Cenk saz çal. & Ali atla \\
\hline & Tan tel al. & Ela ata ot at. \\
\hline & Gül iç. & Mert tat. \\
\hline & Sarp oy ver. & Emir ok at. \\
\hline & Tunç git. & Meral sulu elma al. \\
\hline & Berk gül at. & Emir anteni tamir et. \\
\hline
\end{tabular}

Sınıf öğretmeni deneysel uygulamanın yapıldığı derslere gözlemci olarak katılmıştır. Araştırmacı, her oturumdan bir gün önce etkinlik için gerekli olan malzeme ve ortamı sınıf öğretmeni ile birlikte hazırlamıştır. Oturumlardaki etkinliklere başlamadan önce çocuklara ne yapacakları anlatılmış, herkes ne yapılacağını anladıktan sonra etkinliğin uygulamasına geçilmiştir.

Planlanan oturumlar tamamlandıktan sonra son test uygulanarak deneysel işlemler tamamlanmıştır. Deney grubundaki öğrencilere uygulanan öğretim programının öğrenciler üzerindeki uzun süreli etkilerini değerlendirmek amacıyla son testler uygulandıktan bir ay sonra kalıcılık testleri uygulanmıştır. Ancak, bu süreç içerisinde öğrencilerin formal ilk okuma yazma öğretimi devam ettiğinden dolayı bu durumun elde edilen verilerin geçerliliğini etkileyeceği düşünülmüş ve kalıcılık testlerinin analizine araştırmada yer verilmemiştir.

Kontrol grubunda yer alan ögrencilerle yürütülen işlemler, ön testlerin uygulanması ile başlamıştır. Bu işlemin tamamlanmasından sonra, kontrol grubuna herhangi bir deneysel uygulama (sesbilgisel farkındalık öğretimi) yapılmamış, eğitim ve öğretim süreci deney grubunda olduğu gibi sınıf öğretmeni tarafından Illkokul Türkçe Dersi Öğretim Programı kapsamında, yer alan uygulamalar doğrultusunda yürütülmüştür. 8 hafta sonra son testler uygulanarak deneysel işlem tamamlanmıştır.

\section{Verilerin Analizi}

Araştırma kapsamında deney ve kontrol grubundaki öğrencilerin sesbilgisel farkındalık, yazı farkındalığı becerileri ve kelime bilgisi deneysel işlem öncesinde ve sonrasında ölçülmüştür. Deney ve kontrol grubundaki öğrencilerin ön test - son test puanları arasındaki farkın anlamlılı̆ı bağımlı (ilişkili) gruplar t testi, Wilcoxon işaretli sıralar testi ile deney ve kontrol grubundaki öğrencilerin son test puanları arasındaki farkın anlamlılığı ise bağımsız (ilişkisiz) gruplar t testi ve Mann-Whitney $U$ (MWU) testi ile incelenmiştir. Analizlerde anlamlılık düzeyi ".05" olarak kabul edilmiştir.

Araştırmanın, son test puanlarına ilişkin elde edilen anlamlı farkın düzeyini saptamak amacıyla etki büyüklüğü değerleri incelenmiştir. Bağımsız gruplar t-testinde etki değeri için " $\eta$ " değeri hesaplanmıştır. Eta-kare $\left(\eta^{2}=\frac{t^{2}}{t^{2}+\left(n_{1}+n_{2}-2\right)}\right)$ aldığı değere göre “.01- .06" düşük düzeyde etki, ".06- .14" 
orta düzeyde etki ve “.14 ve üstü” yüksek düzeyde etki şeklinde yorumlanmaktadır (Büyüköztürk, 2011; Pallant, 2007). MWU testinde etki değeri için " $r$ " değeri hesaplanmıştır. Etki büyüklüğü katsayısı $\left(r=\frac{|Z|}{\sqrt{N}}\right)$ aldığı değere göre ".10-.30" düşük düzeyde etki, “.30-.50" orta düzeyde etki ve ".50 ve üzeri” yüksek düzeyde etki şeklinde yorumlanmaktadır (Aron, Aron ve Elliot, 2014; Connolly, 2007: 218; Corder ve Foreman, 2009: 39).

\section{Geçerlik ve Güvenirlik}

Veri toplama araçları biri araştırmacı diğeri de MEB'de çalışan bir öğretmen olmak üzere iki uygulayıcı tarafından ön test ve son test olarak uygulanmıştır. İki uygulayıcı arasındaki Cohen Kappa katsayısı SBFÖ için "1 ( $p<.05)$ ” , FFÖ için "1 ( $p<.05)$ ”, YFDKL için “0.866 (p<.05)”, PRKT için "1 ( $p<.05)$ ” ve toplamda ise "0.990" ( $p<.05)$ " olarak tespit edilmiştir. Kappa değerinin $k<0.01$ olması hiç uyumun olmadığını, ".01-.20" olması önemsiz uyumun varlı̆ı̆nı, ".21-.40" zayıf, ".41-.60" orta düzeyde, ".61$.80 "$ yeterli ve ".81- 1.00" ise mükemmel uyumun varlığını göstermektedir (Kılıç, 2015: 143). Bu bulgu uygulayıcılar arasında uyumun oldukça yüksek olduğunu göstermiştir.

Ölçeklerin uygulanma süresi uzun olduğundan, öğrencilerin yorulmaması için; bir ölçek, çalışma grubundaki öğrencilerin tamamına uygulandıktan sonra diğer ölçeğin uygulamasına geçilmiştir. Uygulamalar, uygulayıcıların ve öğrencilerin rahatça çalışabilecekleri, ısı, ses ve aydınlatma açılarından uygun olan iki boş derslikte yürütülmüştür.

Ölçüm güvenirliği için, veri toplama araçlarına ait deney ve kontrol grubundan elde edilen ön test ve son test ölçümlerinin güvenirlik analizleri yapılmıştır. SBFÖ, FFÖ ve YFDL' nin ön test ve son test ölçümlerine ait K-20 güvenirlik katsayıları Tablo 3'te gösterilmiştir.

Tablo 3.

Deney ve kontrol grubunun SBFÖ, FFÖ ve YFDL'ne ait ön test ve son test ölçümlerinin $K-20$ güvenirlik katsayıları

\begin{tabular}{llccc}
\hline Gruplar & Ölçüm & $\begin{array}{c}\text { SBFÖ } \\
\text { K-20 }\end{array}$ & $\begin{array}{c}\text { FFÖ } \\
\text { K-20 }\end{array}$ & $\begin{array}{c}\text { YFDL } \\
\text { K-20 }\end{array}$ \\
\hline \multirow{2}{*}{ Deney } & Ön Test & .91 & .82 & .72 \\
& Son Test & .95 & .87 & .78 \\
\hline \multirow{2}{*}{ Kontrol } & Ön Test & .90 & .80 & .77 \\
\cline { 2 - 5 } & Son Test & .94 & .77 & .70 \\
\hline
\end{tabular}

Tablo 3 incelendiğinde SBFÖ, FFÖ ve YFDL' nin ön test ve son test ölçümlerine ait güvenirlik katsayılarının (K-20 2.70) yeterli düzeyde olduğu görülmüştür (Büyüköztürk, 2011: 171, Tavşancıl, 2010: 29). PRKT' nin puan hesaplama sistemi farklı olduğu için deney ve kontrol gruplarındaki öğrencilerin ön test ve son test ölçümlerinin güvenirlik değerleri hesaplanmamıştır.

Biri deney, biri kontrol grubu olmak üzere belirlenen sınıflara iki ayrı sınıf öğretmeni girmektedir. İki ayrı öğretmenin olması ders işleme süreçlerinde farklılık yaratacağından, deneysel işleme başlamadan önce öğretmenlerle gerekli görüşmeler yapılmıştır. Özellikle öğretmenlerin uygulama öncesinde işlenecek ünitelerin süreleri, ders planları, derste kullanılacak materyaller ve kullanılacak etkinlikler konusunda, ortak bir görüşle hareket etmeleri istenmiştir. Ayrıca araştırmanın sağlıklı bir şekilde yürütülmesi için belirli aralıklarla, her iki grupta da gözlemler yapılmış uygulamaların ilkokul 1. Sınıf Türkçe Dersi Öğretim Programına uygunluğu ve yapılan uygulamaların birbirine paralel yürütülüp yürütülmediği kontrol edilmiş ve öğretmenlerin, uygulamaları Illkokul 1. Sınıf Türkçe Dersi Öğretim Programına uygun ve birbirine paralel yürüttükleri görülmüştür.

\section{Bulgular}

Kontrol grubundaki öğrencilerin "sesbilgisel farkındalık becerilerinin, yazı farkındalığı becerilerinin ve kelime bilgisinin" gelişimini incelemek amacıyla SBFÖ, FFÖ, YFDL ve PRKT'e ait ön test ile son test puan ortalamaları arasındaki fark analiz edilmiş ve yapılan analiz sonuçlarına Tablo 4'te yer verilmiştir. 
Tablo 4.

Kontrol grubunun SBFÖ, FFÖ, YFDL ve PRKT'e ait ön test ve son test puanlarına ilişskin analiz sonuçları

\begin{tabular}{|c|c|c|c|c|c|c|c|c|}
\hline \multicolumn{9}{|c|}{ Bağımlı Gruplar t-Testi Sonuçları } \\
\hline Grup & Ölçek & Ölçüm & $\mathrm{N}$ & $x$ & $\mathrm{~S}$. & $\mathrm{t}$ & sd & $\mathrm{p}$ \\
\hline \multirow[t]{6}{*}{ Kontrol } & \multirow{2}{*}{$\begin{array}{l}\text { SBFÖ } \\
\text { (Sesbilgisel Farkın.) }\end{array}$} & Ön Test & 23 & 16.26 & 7.94 & \multirow[t]{2}{*}{-7.08} & \multirow[t]{2}{*}{22} & \multirow[t]{2}{*}{$.000^{*}$} \\
\hline & & Son Test & 23 & 25.47 & 10.32 & & & \\
\hline & \multirow{2}{*}{$\begin{array}{l}\text { FFÖ } \\
\text { (Sesbilgisel Farkın.) }\end{array}$} & Ön Test & 23 & 6.69 & 4.08 & \multirow[t]{2}{*}{-6.88} & \multirow[t]{2}{*}{22} & \multirow[t]{2}{*}{$.000^{*}$} \\
\hline & & Son Test & 23 & 16.60 & 6.29 & & & \\
\hline & \multirow{2}{*}{$\begin{array}{l}\text { PRKT } \\
\text { (Kelime Bilgisi) }\end{array}$} & Ön Test & 23 & 6.91 & 1.24 & \multirow[t]{2}{*}{-2.79} & \multirow[t]{2}{*}{22} & \multirow[t]{2}{*}{$.011^{*}$} \\
\hline & & Son Test & 23 & 7.74 & 1.13 & & & \\
\hline \multicolumn{9}{|c|}{ Wilcoxon İşaretli Sıralar Testi Sonuçları } \\
\hline Grup & Ölçek & $\begin{array}{l}\text { Son Test- } \\
\text { Ön Test }\end{array}$ & $\mathrm{N}$ & $\begin{array}{c}\text { Sira } \\
\text { Toplamı }\end{array}$ & \multicolumn{2}{|c|}{ Sıra Ortalaması } & $z$ & $p$ \\
\hline \multirow[t]{3}{*}{ Kontrol } & \multirow{3}{*}{$\begin{array}{l}\text { YFDL } \\
\text { (Yazı Farkındalığı) }\end{array}$} & Negatif & 1 & 2.50 & \multicolumn{2}{|c|}{2.50} & $3.93 * *$ & \multirow[t]{3}{*}{$.000 *$} \\
\hline & & Pozitif & 20 & 11.43 & \multicolumn{2}{|c|}{228.50} & & \\
\hline & & Eşit & 2 & - & \multicolumn{2}{|c|}{-} & & \\
\hline
\end{tabular}

**Negatif sıralar temeline dayalı, $* p<.05$

Tablo 4 incelendiğinde, kontrol grubu öğrencilerinin ön test ve son test puan ortalamaları arasında; SBFÖ [t(22)=-7.08; $p<.05]$; FFÖ [t(22)=-6.88; $p<.05]$; YFDL $(z=3.93 ; p<.05)$ ve PRKT'e [t(22)=$2.79 ; p<, 05$ ] göre son test lehine anlamlı farklılık olduğu tespit edilmiştir. Bu durum kontrol grubundaki öğrencilerin sesbilgisel farkındalık, yazı farkındalığı ve kelime bilgisi düzeylerinde artış olduğu şeklinde yorumlanabilir.

Deney grubundaki öğrencilerin "sesbilgisel farkındalık becerilerinin, yazı farkındalığı becerilerinin ve kelime bilgisinin" gelişimini incelemek amacıyla SBFÖ, FFÖ, YFDL ve PRKT'e ait ön test ile son test puan ortalamaları arasındaki fark analiz edilmiş ve yapılan analiz sonuçlarına Tablo 5 'te yer verilmiştir.

Tablo 5.

Deney grubunun SBFÖ, FFÖ, YFDL ve PRKT'e ait ön test ve son test puanlarına ilişkin analiz sonuçları

\begin{tabular}{|c|c|c|c|c|c|c|c|c|}
\hline \multicolumn{9}{|c|}{ Bağımlı Gruplar t-Testi Sonuçları } \\
\hline Grup & Ölçek & Ölçüm & $\mathrm{N}$ & $x$ & S. & $\mathrm{t}$ & sd & $\mathrm{p}$ \\
\hline \multirow[t]{6}{*}{ Deney } & \multirow{2}{*}{$\begin{array}{l}\text { SBFÖ } \\
\text { (Sesbilgisel Farkın.) }\end{array}$} & Ön Test & 24 & 16.16 & 7.99 & \multirow[t]{2}{*}{-16.95} & \multirow[t]{2}{*}{23} & \multirow[t]{2}{*}{$.000 *$} \\
\hline & & Son Test & 24 & 50.00 & 10.25 & & & \\
\hline & \multirow{2}{*}{$\begin{array}{l}\text { FFÖ } \\
\text { (Sesbilgisel Farkın.) }\end{array}$} & Ön Test & 24 & 6.20 & 4.08 & \multirow[t]{2}{*}{-15.62} & \multirow[t]{2}{*}{23} & \multirow[t]{2}{*}{$.000^{*}$} \\
\hline & & Son Test & 24 & 32.41 & 3.90 & & & \\
\hline & \multirow{2}{*}{$\begin{array}{l}\text { PRKT } \\
\text { (Kelime Bilgisi) }\end{array}$} & Ön Test & 24 & 6.72 & 1.37 & \multirow[t]{2}{*}{-8.22} & \multirow[t]{2}{*}{23} & \multirow[t]{2}{*}{$.000^{*}$} \\
\hline & & Son Test & 24 & 9.13 & 1.09 & & & \\
\hline \multicolumn{9}{|c|}{ Wilcoxon İşaretli Sıralar Testi Sonuçları } \\
\hline Grup & Ölçek & $\begin{array}{l}\text { Son Test- } \\
\text { Ön Test }\end{array}$ & $\mathrm{N}$ & \multicolumn{2}{|c|}{$\begin{array}{r}\text { Sıra } \\
\text { Toplamı }\end{array}$} & $\begin{array}{r}\text { Sıra } \\
\text { talaması }\end{array}$ & $z$ & $\mathrm{p}$ \\
\hline \multirow[t]{3}{*}{ Deney } & \multirow{3}{*}{$\begin{array}{l}\text { YFDL } \\
\text { (Yazı Farkındalığı) }\end{array}$} & Negatif & 0 & & .00 & .00 & \multirow[t]{3}{*}{$4.29 * *$} & \multirow[t]{3}{*}{$.000^{*}$} \\
\hline & & Pozitif & 24 & & .50 & 300.00 & & \\
\hline & & Eşit & 0 & & - & - & & \\
\hline
\end{tabular}

**Negatif sıralar temeline dayalı, $* p<.05$

Tablo 5 incelendiğinde, deney grubu öğrencilerinin ön test ve son test puan ortalamaları arasında; SBFÖ [t(23)=-16.95; $p<.05]$; FFÖ [t(23)=-15.62; $p<.05]$; YFDL $(z=4.29 ; p<.05)$ ve PRKT'e [t(23)=- 
8.22; $p<.05$ ] göre son test lehine anlamlı farklılık olduğu tespit edilmiştir. Bu durum deney grubundaki öğrencilerin sesbilgisel farkındalık, yazı farkındalığı ve kelime bilgisi düzeylerinde artış olduğu şeklinde yorumlanabilir.

Deneysel işlem sonrası (son test), sesbilgisel farkındalık, yazı farkındalığı ve kelime bilgisinden oluşan erken okuryazarlık becerilerinin gelişimi açısından, deney ve kontrol grubu arasındaki farkın anlamlılığının incelenmesi amacıyla; deney ve kontrol grubunun, SBFÖ, FFÖ, YFD ve PRKT'e ait son test puanları arasındaki fark analiz edilmiş ve yapılan analiz sonuçlarına Tablo 6 'da yer verilmiştir.

Tablo 6.

Deney ve kontrol grubunun SBFÖ, FFÖ, YFDL ve PRKT'e ait son test puanlarına ilişkin analiz sonuçları

\begin{tabular}{|c|c|c|c|c|c|c|c|c|c|c|c|}
\hline \multicolumn{12}{|c|}{ Bağımsız Gruplar t-Testi Sonuçları } \\
\hline \multirow{2}{*}{ Ölçüm } & \multirow{2}{*}{ Ölçek } & \multirow{2}{*}{ Grup } & \multirow{2}{*}{$\mathrm{N}$} & \multirow{2}{*}{$x$} & \multirow{2}{*}{ ss. } & \multicolumn{2}{|c|}{ Levene Testi } & \multirow{2}{*}{$\mathrm{t}$} & \multirow{2}{*}{$\mathrm{sd}$} & \multirow{2}{*}{$\mathrm{p}$} & \multirow{2}{*}{$\eta^{2}$} \\
\hline & & & & & & $\mathrm{F}$ & $p$ & & & & \\
\hline \multirow{6}{*}{ Son Test } & \multirow[t]{2}{*}{ SBFÖ } & Deney & 24 & 50.00 & 10.25 & \multirow[t]{2}{*}{.30} & \multirow[t]{2}{*}{.581} & \multirow[t]{2}{*}{8.16} & \multirow[t]{2}{*}{45} & \multirow[t]{2}{*}{$.000^{*}$} & \multirow[t]{2}{*}{.60} \\
\hline & & Kontrol & 23 & 25.47 & 10.32 & & & & & & \\
\hline & \multirow[t]{2}{*}{ FFÖ } & Deney & 24 & 32.41 & 3.90 & \multirow[t]{2}{*}{3.32} & \multirow[t]{2}{*}{.750} & \multirow[t]{2}{*}{10.39} & \multirow[t]{2}{*}{45} & \multirow[t]{2}{*}{$.000^{*}$} & \multirow[t]{2}{*}{.71} \\
\hline & & Kontrol & 23 & 16.60 & 6.29 & & & & & & \\
\hline & \multirow[t]{2}{*}{ PRKT } & Deney & 24 & 9.13 & 1.09 & \multirow[t]{2}{*}{.79} & \multirow[t]{2}{*}{.378} & \multirow[t]{2}{*}{4.28} & \multirow[t]{2}{*}{45} & \multirow[t]{2}{*}{$.000 *$} & \multirow[t]{2}{*}{.29} \\
\hline & & Kontrol & 23 & 7.74 & 1.13 & & & & & & \\
\hline \multicolumn{12}{|c|}{ MWU Testi Sonuçları } \\
\hline Ölçüm & Ölçek & Grup & $\mathrm{N}$ & & Ort. & Sira Top. & $U$ & $z$ & & $p$ & $r$ \\
\hline \multirow{2}{*}{ Son Test } & \multirow{2}{*}{ YFDL } & Deney & 24 & & .94 & 790.50 & 61.50 & -4.6 & & $.000 *$ & .67 \\
\hline & & Kontrol & 23 & & .67 & 337.50 & & & & & \\
\hline
\end{tabular}

${ }^{*} p<.05$

Tablo 6 incelendiğinde, deney grubu ve kontrol grubundaki öğrencilerinin son test puan ortalamaları arasında; SBFÖ [t(45)=8.16 $\left.p<.05 ; \eta^{2}=.60\right]$; FFÖ [t(45)=10.39 $\left.p<.05 ; \eta^{2}=.71\right]$; YFDL ( $\mathrm{MWU}=61.50 ; p<.05 ; r=.67$ ) ve PRKT'e $\left[\mathrm{t}(45)=4.28 p<.05 ; \eta^{2}=.29\right]$ göre deney grubu lehine anlamlı farklıık olduğu tespit edilmiştir Bu deneysel işlem sonrası, SBFP'nın uygulandığı deney grubunun, "sesbilgisel farkındalık, yazı farkındalı̆ı̆ ve kelime bilgisi" düzeyinin kontrol grubundan anlamlı şekilde daha yüksek olduğu görülmüştür. Bu bulgu, SBFP'nın öğrencilerin sesbilgisel farkındalık becerilerinin, yazı farkındalı̆̆ı becerilerinin ve kelime bilgisinin gelişimi üzerinde etkili olduğu şeklinde yorumlanabilir. Araştırmanın, son test puanlarına ilişkin elde edilen anlamlı farkın düzeyini saptamak için hesaplanan " $\eta 2$ " değerleri ve " $r$ " değerleri, sesbilgisel farkındalık, yazı farkındalığı ve kelime bilgisi" düzeylerinde deney grubu lehine olan farklar üzerine SBFP'nın yüksek düzey etkiye sahip olduğunu göstermektedir.

\section{Tartışma ve Sonuç}

Erken okuryazarlık, formal okuryazarlığa öncülük eden ve gelişen okuma ve yazma davranışlarıdır (Sulzby ve Teale, 1991: 728). Okul öncesi dönemde desteklenen erken okuryazarlık becerileri çocukların formal eğitime başladıkları ilkokuldaki okuma yazma becerilerinin gelişimini desteklemekte; başka bir deyişle okuma yazmanın temelini oluşturmaktadır (Taşkın, Sak ve Sak, 2015: 330). Gozali-Lee ve Dan Mueller (2013) yaptıkları araştırmada, erken okuryazarlık becerilerinin okumayazma becerilerinin gelişimi üzerine olumlu bir etkisi olduğu bulunmuş, Kaminski ve Good (1998: 113) da başarılı okuma eğitimi ve okuma problemlerinin önlenmesi için, çocukların erken okuryazarlık becerilerine sahip olması gerektiğini vurgulamıştır. Çocukların okumayı öğrenmeleri için, yazılı dili ve sözlü dili fark etmeleri ve bunlar arasında bağ kurmaları gerekmektedir. Çocukların sözlü dilin yapısına ilişkin ses bilgisini edinmeleri için sesbilgisel farkındalık becerileri; yazılı dilin yapısına ilişkin yazı kavramı ve harf bilgisinin edinmesi için de yazı farkındalı̆ı̆ becerileri ve alfabe bilgisi gereklidir. Sesbilgisel farkındalık ve yazı farkındalığı ise erken okuryazarlığı oluşturan beceri alanlarından bazılarıdır. Okumayazma ile ilgili araştırma yapan araştırmacılar, erken okuryazarlığın temeli olan çeşitli beceri alanları belirlemişlerdir. Bu beceri alanlarını, Gozali-Lee ve Dan Mueller (2013), alfabe bilgisi, sesbilgisel 
fakındalık, sesbilgisel hafıza, hızı isimlendirme, harf yazma; Israel (2008), sesbilgisel farkındalık, yazı farkındalığı, alfabe bilgisi ve sözlü dil becerileri; Kargın, Ergül, Büyüköztürk ve Güldenoğlu (2015), kelime bilgisi, sesbilgisel farkındalık, yazı farkındalığı, harf bilgisi ve dinlediğini anlama; Pullen ve Justice (2003), sesbilgisel farkındalık, yazı farkındalı̆ı ve sözel dil becerileri olarak sınıflandırmıştır. Bu çalışmada erken okuryazarlık becerilerinden sadece; (1)sesbilgisel farkındalık, (2)yazı farkındalığı ve (3)kelime bilgisi ele alınmıştır.

Sesbilgisel farkındalık, Torgesen ve Mathes'e (1998: 3) göre dili oluşturan sesleri fark edebilme, sesler hakkında düşünebilme ve sesleri manipüle edebilme (hece veya ses silme, ekleme ve değiştirme vb.) becerisi; Blachman'a (2000: 483) göre anlamdan ziyâde, konuşmadaki yapıların sesbilgisel bileşenlerinin farkında olma olarak tanımlanmıştır. Bu tanımlara göre, sesbilgisel farkındalık, anlamdan bağımsız bilinçli olarak sözel dilin daha küçük birimlere (kelime-hece-sesbirim) ayrılacağının farkında olma, konuşma dilinde yer alan sesbirimleri fark etme, tanıma, analiz etme ve onları etkili şekilde kullanabilme becerisidir (Gökkuş ve Akyol, 2020: 309). Sesbilgisel farkındalık, çeşitli gelişim aşamalarından ve bu gelişim aşamalarında gerçekleştirilebilmesi gereken sesbilgisel farkındalık görevlerinden oluşur (Erkan Süel, 2011: 13). Kelime düzeyinde başlayan sesbilgisel farkındalık görevleri, aşamalı bir şekilde kelimelerden daha küçük parçalara doğru ilerler (Erdoğan, 2009: 28). Rathvon (2004: 67), sesbilgisel farkındalık görevlerini, sesbirim olmayan ve sesbirim (birbirinden bağımsız sesleri algılama ve kullanma becerileri) olmak üzere iki bölüme ayırmıştır. Sesbirim olmayan bölüm, uyak, kelime, hece, ilk ses-son ses becerilerini; sesbirim bölümü ise birbirinden bağımsız sesleri algılama ve kullanma becerilerini içermektedir.

Yapılan çeşitli araştırmalarda, bu dil becerisi ile okuma arasında karşılıklı bir ilişki olduğu ortaya konulmuştur (Erdoğan, 2009; Erkan Süel, 2011; Gül, 2006; Karakelle, 2004; Turan ve Gül, 2008). Sesbilgisel farkındalık becerileri özellikle sesbirim farkındalığı söylenen kelimenin, ses özelliklerini kodlayarak, yazılı kelimenin kavranması için gerekli olan alfabetik ilkelerin geliştirilmesine katkı sağlar. Yazılı kelimenin kodunu çözmek için, bir yazma sisteminin mantığını ve bir ön koşul olarak sözlü kelime üretiminin mantığını anlamak gerekir (Hempenstall, 1997: 9). Bu yüzden sesbirim farkındalığı, çocukların metin içindeki sesbilgisel olarak kod çözme yetenekleri üzerindeki etkisi ile okumanın gelişmesinde birincil etkiye sahiptir (Torgesen ve Mathes, 1998: 4).

Sesbilgisel farkındalık, verilen öğretimlerle gelişebilen bir beceridir (Aktan Kerem, 2001; Bayraktar, 2013). Turan ve Akoğlu'un (2011) yaptıkları araştırmada uyak farkındalığı, kelime farkındalığı ve sesbirim farkındalığı aşamalarını içeren sesbilgisel farkındalık öğretiminin sesbilgisel farkındalık becerilerini olumlu yönde etkilediği bulunmuştur. Kozminsky ve Kozminsky (1995) yaptıkları araştırmada Lundberg vd. (1988) tarafından hazırlanan sesbilgisel farkındalık öğretim programını uygulamış ve bu programın sesbilgisel farkındalık becerileri, okuduğunu anlama ve okumayı edinme üzerine etkisini incelemiştir. Araştırma sonucunda, uygulan programın genel sesbilgisel farkındalık becerilerini, okuduğunu anlamayı anlamlı bir şeklide geliştirdiği bulunmuştur. Bu çalışmadan elde edilen bulgularda da, SBFP kapsamında verilen sesbilgisel farkındalık öğretiminin, birinci sınıf öğrencilerinin sesbigisel farkındalık becerilerini geliştirdiği görülmüştür.

Yazı farkındalığı, sesbilgisel farkındalık ile birlikte, geleneksel okuryazarlığın temel yapı taşları olarak görülmektedir (Justice ve Ezel, 2001: 209). Yazı farkındalığı, ilk olarak 1960 yılında Clay tarafından ifade edilmiştir (Bayraktar, 2013: 44). Yazılı dilinin kurallarının, işlevinin ve yazılı dil ile sözel dil arasındaki ilişkinin anlaşılması olarak tanımlanmaktadır (Justice ve Ezel, 2001: 208). Rathvon (2004: 112) yazı farkındalığını, yazının işlevini fark etme ve yazının kurallarını fark etme olarak ele almıştır. 1)Yazının işlevini fark etme, yazının iletişimdeki rolünün anlaşılması olarak tanımlanmıştır (okunan hikâyede söylenenlerin yazılı işaretlerle temsil edildiğini ve bilgi verdiğini, okumanın farklı amaçları olduğunun kavranması vb). 2)Yazının kurallarını fark etme ise yazının özelliğini ve mekaniğinin bilgisi olarak ifade edilmiştir (yazının soldan sağa, yukardan aşağıya doğru ilerlediği, kelimelerin arasında boşluklar olduğunun, kelimelerin harflerden oluştuğunu farkında olma vb). Israel (2008: 48-49) yazılı dilin amacının iletişim kurmak olduğunu ve kâğıtta yer alan işaretlerin bir anlam taşıdığını (yazı kavramı) kavrayan; çevresel yazıları fark eden, harflerin isimleri olduğunu ve kelimelerin farklı biçim ve şekillerinin olduğunu anlayan (harf kavramı); yazı ve resimler, harfler ve kelimeler, kelimeler ve aralarındaki boşluklar arasındaki ayrımı yapan (kelime kavramı); yazının soldan sağa ve yukarıdan 
aşağıya doğru bir akış yönü olduğunu bilen (yazı kavramı); bir kitabın kısımlarını ve amaçlarını tanıyan (kitap kavramı); noktalama işaretlerinin bir amacının olduğunu bilen ve fark eden (noktalama kavramı); gördüğü kelimelerin bazılarını tanıyan, tanıdığı yazılı sembolleri yazmaya çalışan bir çocuğun yazı farkındalığının gelişmeye başladığını belirtmiştir.

Yazı farkındalığı okuma becerilerinin edinilmesine katkı sağlamakta ve okumanın edinilmesiyle de yerleşmektedir. Bay, Altun ve Çetin (2014: 255), yazı farkındalığının çocukların gelecekteki okuma becerilerini ön gören, en güçlü becerilerden birinin olduğunu ifade etmiş; Weir (1989: 458) de erken yaşlarda, yazı kavramlarına sahip olmanın okumayı kolaylaştırdığını ve okumanın öğrenilmesi için gerekli olduğunu saptamıştır. Çocukların yazı farkındalığı ile sesbilgisel farkındalığı birleştirerek, okuma yazma farkındalığını kazanmaları sağlanmalıdır (Şimşek, 2011). Carroll, Bowyer-Crane Duff, Hulme, Margaret ve Snowling (2011: 8) göre, okul öncesi dönemde sesbilgisel farkındalık ve yazı farkındalığı becerileri birbirleri ile etkileşim içindedir ve bu iki temel beceri okuma becerilerinin edinilmesinde önemli bir rol oynamaktadır. Morris (1993) yaptıları çalışmada sesbirim farkındalığının gelişmesi için kelime kavramının öğrenilmesi gerektiği ve bunların birbirini ile etkileşim içinde olduğu belirtilmiştir. Bazı yazarlara göre yazılı dilin özellikleri, çocuğun sesbilgisel açıdan kelime farkındalığının gelişmesi için gerekli olduğu gibi (Kolinsky, Cary ve Morais, 1987: 223); çocuğun yazılı dildeki sesleri ve kelimeleri birbirinden ayrı olarak duyması da yazılı dildeki harf ve kelime farkındalı̆ının gelişimi için gereklidir (Bayraktar, 2013: 60). Ayrıca çocukların, cümlelerin kelimelerden, kelimelerin hece ve sesbirim gibi daha küçük birimlerden oluştuğunu anlaması, onların yazılı dilin kodlarını çözmelerini ve söylenen kelimelerin yazılı kelimelerle eşleştirmelerini yani ses-harf eşleştirme becerisini edinmelerini kolaylaştırmaktadır (Phillips, Clancy-Menchetti ve Lonigan, 2008: 2).

Yazı farkındalığı, verilen öğretimlerle gelişebilen bir beceridir (Bayraktar, 2013; Şimşek, 2011). Bu çalışmadan elde edilen bulgularda da, SBFP kapsamında verilen sesbilgisel farkındalık öğretiminin, birinci sınıf öğrencilerinin yazı farkındalığı becerilerini geliştirdiği görülmüştür.

Kelime bilgisi, bir kişinin anlamını bildiği, okuduğu-dinlediği zaman tanıdığı, konuşurkenyazarken kullandığı kelimelerin tümü olarak kabul edilebilir. Sözel dil ve kelime bilgisi, erken çocukluk dil ve okuma yazma gelişiminde önemli bir rol oynamaktadır. Sözel dil ve kelime bilgisi sadece konuşma becerilerini değil aynı zamanda okuma ve yazma becerilerini de güçlü bir şekilde etkilemektedir (Beauchat, Blamey ve Walpole, 2010: 17). Beck ve McKeown, (2007) yaptıkları araştırmada okuma becerisi ile kelime bilgisi arasında güçlü bir ilişkinin olduğunu ortaya koymuşlardır. Güneş (2014) çok kelime duyan ve anlamını bilen çocukların, okumayı daha kolay öğrendiklerini; Allor (2002:3) ise kelime bilgisi yetersiz olan çocukların okumayı öğrenmede zorluk yaşadıklarını ifade etmiştir. Rief ve Stren (2010: 98) kelime bilgisini okuma başarısını belirleyen en temel faktör olarak tanımlamıştır. Kelime bilgisinin okuma üzerindeki rolünü belirlemek için, kelime bilgisi genişliği (bilinen kelime sayısı) ve kelime bilgisi derinliği (kelimenin ne kadar bilindiği) kavramları arasında bir ilişki kurmak gerekir. Son zamanlarda yapılan araştırmalar, kelime bilgisi genişliğinin (kelimelerin sesbilgisel yapılarına dayanır) doğrudan sesbirim farkındalığı ve kod çözme becerileri ile ilişkili olduğunu; kelime bilgisi derinliğinin ise (kelimelerin anlamsal temsilinin zenginliğine dayanır), daha sonraki okuduğunu anlama becerilerini önemli bir yordayıcısı olduğunu göstermiştir (Kleeck, 2008: 631).

Sözel dil, kod çözme becerilerinin gelişimini doğrudan desteklemesede sesbilgisel farkındalığın gelişmesi içinde olası bir kaynaktır ve özellikle okul öncesi dönemde aralarında sıkı bir ilişki vardır (Lonigan, 2007: 21-22). Sénéchal, Ouellette ve Rodney (2006) yaptıkları çalışmada çocuğun kelime bilgi seviyesi artıkça, kelimelerin farklı formlarını gördüğünü, böylelikle kelimelerin daha küçük birimlere bölünebileceğini fark ettiklerini ve bunun da sesbilgisel farkındalığı olumlu yönde etkilediğini ifade etmişlerdir. Burgess ve Lonigan (1998) orta sosya-ekonomik düzeyde olan 4 yaşındaki 98 öğrenciyle yaptıkları boylamsal araştırma sonunda, çocukların sahip oldukları kelime bilgisinin bir yıl sonraki sesbilgisel farkındalık becerilerinin yordayıcısı olduğunu bulmuştur. Llyod, Quinn ve Butterfield (1990) öğrencilerin kelime gelişimi ile sesbilgisel farkındalık becerileri arasında nedensel bir ilişikini olduğunu, sesbirim öğretiminin çocukların kelime gelişimine yardım ettiğini ifade etmiştir. Cooper, Roth, Speece ve Schatschneider (2002) sesbilgisel farkındalığın, sözel dili ve okuma başarısını arttırdığını ortaya koymuştur. Araştırmalardan elde edilen sonuçlar sesbilgisel farkındalık ve kelime bilgisi arasında eş zamanlı ve uzun süreli ilişkiler olduğunu göstermektedir. Bazı veriler, kelime bilgisinin sesbilgisel 
farkındalığın gelişimini yordadığını ortaya koymuştur. Kelime bilgisi ve sesbilgisel farkındalık arasındaki ilişki sözcüksel yeniden yapılandırma modeli ile de açıklanmaktadır (Lonigan, 2007: 24). Dil edinimin içsel bir parçası olan "sözcüksel yeniden yapıldırma" sürecinin bir sonucu olarak sesbilgisel farkındalığın gelişebileceği düşünülmektedir. Sözcüksel yeniden yapılandırma modeli, normal gelişim sürecinde çocukların sesbilgisel temsillerinin yaşla birlikte fonetik özellikler açısından giderek daha kesin ve açık bir şekilde belirlendiği önermesine dayanmaktadır (Goswami, 2001: 5). Kelime dağarcığı az alan küçük çocukların bildikleri kelimelerin söz dizimi belleğe bütünsel olarak kaydedilir. Okul öncesi ve erken okul yıllarında çocuklar daha fazla kelime öğrendikçe, kelimeleri, birer birer değil, bileşen parçaları açısından hatırlamanın ve tanımanın daha verimli olduğunu anlarlar (Lonigan, 2007: 24). Yeniden yapılanma, büyük ölçüde kelime dağarcığına bağlı olduğu için uzun sürelidir. Aşina olunan ve sesbilgisel açıdan benzer olan kelimelerin öğrenilmesi artıkça kademeli olarak kelimelerin belleğe kaydedilmesi bütünden daha küçük birimlere ve parçalara doğru hareket etmektedir (Walley, Metsala ve Garlock, 2003:6). Örneğin, bir çocuk "kar", "zar", "nar", "kan", "kas", kör ve "kir" kelimelerine aşina olduğunda, bu kelimelerin hepsinin tek bir ses ile "kar" kelimesinden farklı olduğunu anlaması ve benzeri sesleri olan bu kelimeleri birbirinden hızlı ve doğru bir şekilde ayırt edebilmesi için çocukların zihinsel sözlüğündeki her bir kelimenin ses dizileri ile temsil edilmesi gerekmektedir (Goswami, 2001: 6-7). Bu nedenle sözlüksel yeniden yapılandırma, sesbirim farkındalığını geliştirmekte ve sürdürmektedir (Walley, vd., 2003: 7).

Kelime bilgisi, çocukta okul öncesi dönemde aile ve yaşadığı çevrede şekillenir (Özalp, 2011: 5). Çoğu zaman, tekrar tekrar konuşmalar yaparak, konuşmalardaki yeni kelimeleri, öyküleri dinleyerek ve medya aracılığıyla dolaylı olarak öğrenilir (Konza, 2014: 160). 6 yaşından itibaren çocuğun sahip olduğu dil, okulda belli bir program ve plan doğrultusunda gelişmektedir ve dilin geliştirilmesinde de "kelime öğretimi" büyük önem taşımaktadır (Özbay ve Melanlıoğlu, 2008: 31). Yapılan birçok araştırmada, çocukların kelimeleri kullanma ve anlama düzeylerinin, kelime öğretim etkinlileri ve zengin öğretim programları ile artabileceğini ortaya koymuştur (Beck ve McKeown, 2007; Silverman, 2007). Bu çalışmadan elde edilen bulgularda da, SBFP kapsamında verilen sesbilgisel farkındalık öğretiminin, birinci sınıf öğrencilerinin kelime bilgisi düzeylerini artırdığı görülmüştür.

Sesbilgisel farkındalık, okuma beceresi ile doğrudan ilişkilidir ve okuma becerisinin en güvenilir yordayıcısıdır. Sesbilgisel farkındalıktaki yetersizlik doğrudan okuma becerisindeki yetersizlik ile bağlantılıdır. Erken müdahale programları ile bu becerideki yetersizlikleri giderilebilir ve bu beceri geliştirilebilir. Sesbilgisel farkındalı̆ın gelişmesi de çoğunlukla, diğer erken okuryazarlık becerilerini, okuma ve yazma becerilerini geliştirdiğinden, bu becerilere yönelik öğretim programlarının hazırlanması ve uygulanması önem taşımaktadır.

\section{Kaynaklar}

Adams, M. J., Foorman, B. R., Lundberg, I., \& Beeler, T. (2002). Phonemic awareness in young children: A classroom curriculum. Baltimore: Paul H. Brookes.

Akbey, G.Ö. (2016). Down sendromlu bireylerin akıcı okuma ve okuduğunu anlama ile fonolojik farkındalık düzeyleri arasındaki ilişki. Yüksek Lisans Tezi, Anadolu Üniversitesi Eğitim Bilimleri Enstitüsü, Eşkişehir.

Akdal, D. (2018). Sesbilgisel farkındalık becerilerini desteklemeye yönelik SESFAR müdahale programının etkililiğinin incelenmesi. Doktora Tezi, Ankara Üniversitesi Eğitim Bilimleri Enstitüsü, Ankara.

Akoğlu, G. ve Turan, F. (2012). Phonologıcal awareness as an educatıonal interventıon approach: effects on readıng skılls with mentally retarded chıldren. Hacettepe Unıversitesı Egıtım Fakultesı Dergısı-Hacettepe University Journal Of Educatıon, (42), 11-22.

Aktan Kerem, E. (2001). Okul öncesi dönem çocuklarında okuma gelişimi ve okumaya hazırlık programının etkisinin değerlendirilmesi. Doktora Tezi, Marmara Üniversitesi Eğitim Bilimleri Enstitüsü, İstanbul.

Aktan, E. (1996). Çocuğun dil gelişiminde fonolojik duyarlılığın (sesbirim duyarlılığı) karşılaştırılmalı olarak incelenmesi. Yüksek Lisans Tezi, Marmara Üniversitesi Sosyal Bilimler Enstitüsü, ìstanbul. 
Allor, J. H. (2002). The relationships of phonemic awareness and rapid naming to reading development. Learning Disability Quarterly, 25(1), 47-57.

Aron, A., Aron. E. \& Elliot, C. (2014). Statistics for psychology (6. baskı). London: Pearson.

Balcı, Ö. (2016). Konuşma sesi bozukluğu olan çocuklarda fonolojik farkındalık becerileri ve sözel çalışma belleği arasındaki ilişkinin incelenmesi. Yüksek Lisans Tezi. Hacettepe Üniversitesi Sağlık Bilimleri Enstitüsü, Ankara.

Bay, D. N., Altun, S. A. \& Çetin, Ö. Ş. (2014). Okuma yazmaya hazırlık araştırmalarına yönelik öğretmen görüşleri. Uşak Üniversitesi Sosyal Bilimler Dergisi, 7(1), 244-263.

Bayraktar, V. (2013). Okuma-yazmaya hazırlık eğitim programının anasınıfına devam eden 6 yaş grubu çocukların yazı farkındalığı becerilerine ve ilkokul birinci sınıftaki ses farkındalığı ve okumayazma becerilerine etkisinin incelenmesi. Doktora Tezi. Gazi Üniversitesi Eğitim Bilimleri Enstitüsü, Ankara.

Beauchat, K., Blamey, K. \& Walpole S. (2010). The building blocks of preschool success. New York: The Guilford.

Beck, I. L. ve McKeown, M. G. (2007). Increasing young low-income children's oral vocabulary repertoires through rich and focused instruction. The Elementary School Journal, 107(3), 251271.

Bentin, S., Hammer, R., \& Cahan, S. (1991). The effects of aging and first grade schooling on the development of phonological awareness. Psychological science, 2(4), 271-275.

Blachman, B. A. (2000). Phonological awareness. M. Kamil, Pr Mosenthal, D. Pearson, R. Barr (Ed.), Handbook of Reading Research Volume III (483-503). London: Lawrence Erbaum Associates.

Burgess, S. R., ve Lonigan, C. J. (1998). Bidirectional relations of phonological sensitivity and prereading abilities: evidence from a preschool sample. Journal of experimental child psychology, 70(2), 117-141.

Büyüköztürk, Ş. (2011). Sosyal bilimler için veri analizi el kitabı- istatistik, araştırma deseni SPSS uygulamaları ve yorum. Ankara: PegemA.

Büyüktaşkapu, S. (2012). Adaptation of mountain shadows phonological awareness scale (ms-pas) into turkish and validity and reliability study. International Online Journal of Educational Sciences, 4(2), 509-518.

Carroll, J.M., Bowyer-Crane C., Duff, F.J., Hulme, C., Margaret J. \& Snowling, M., J. (2011). Theoretical framework: foundations of learning to read. Chesher, D. (Ed), Developing language and literacy effective intervention in the early years (pp. 1-16). John Wiley ve Sons, Ltd. ISBN: 978-0-47071186-6.

Chard, D. J., ve Dickson S. V. (1999). Phonological awareness: Instructional and assesment guideliness. Intervention in School and Clinic, 34(5), 261-270.

Cohen, L.; Manion, L. \& Morrison, K. (2000). Research methods in education. (5thedition). London: Routledge Falmer.

Connolly, P. (2007). Quantitative data analysis in education: a critical introduction using spss. Routledge, USA.

Cooper, D. H., Roth, F. P., Speece, D. L., \& Schatschneider, C. (2002). The contribution of oral language skills to the development of phonological awareness. Applied Psycholinguistics, 23(03), 399416.

Corder, G. W. ve Foreman, D. I. (2009). Nonparametric statistics for non statisticians: a stepby-step approach. John Wiley \& Sons, Inc., New Jersey. 15.08.2015 tarihinde http://gtu.ge/AgroLib/0696207 2982C corder g w foreman d i nonparametric statistic.pdf adresinden alınmıştır.

Demirtaş, Ç.P. (2017). Okuma güçlüğü olan öğrencilerde okuma, sesbilgisel farkındalık, hızlı isimlendirme ve çalışma belleği becerilerinin incelenmesi. Yüksek Lisans Tezi, Ankara Üniversitesi Eğitim Bilimleri Enstitüsü, Ankara.

Dinler, H. (2018). Şiir odaklı destekleyici eğitim programının okul öncesi dönemi çocuklarının fonolojik farkındalıklarına etkisi. Yüksek Lisans Tezi, Pamukkale Üniversitesi Eğitim Bilimleri Enstitüsü, Pamukkale. 
Erdoğan, Ö. (2009). İlköğretim birinci sınıf öğrencilerinin fonolojik farkındalık becerileri ile okuma ve yazma becerileri arasındaki ilişki. Yüksek Lisans Tezi, Hacettepe Üniversitesi Eğitim Bilimleri Enstitüsü, Ankara.

Erkan Süel, E. (2011). Ilköğretim 1. sınıf üstün ve normal zekâ düzeyindekiöğrencilerin fonolojik farkındalık düzeylerinin okuma başarıları üzerine etkisinin karşılaştırılması. Yüksek Lisans Tezi. İstanbul Üniversitesi Sosyal Bilimler Enstitüsü, İstanbul.

Goswami, U. (2001). Early phonological development and the acquisition of literacy. Handbook of early literacy research, 1, 111-125.

Gozali-Lee, E., ve Mueller, D. (2013). Early Literacy. 15.08 .2015 tarihinde https://www.wilder.org/sites/default/files/imports/GenerationNext EarlyLiteracyReport 413.pdf adresinden alınmıştır.

Gökkuş, (2016). Erken okuryazarlık becerilerinin gelişiminde ses bilgisi farkındalık programının etkisi. Doktora Tezi. Gazi Üniversitesi Eğitim Bilimleri Enstitüsü, Ankara.

Gökkuş, I., ve Akyol, H. (2020). Ses bilgisi farkındalık programının birinci sınıf öğrencilerinin sesbilgisel farkındalık becerilerinin gelişimine etkisi. Cumhuriyet Uluslararası Eğitim Dergisi, 9(1), 308331.

Gül, G. (2006). Hafif derecede zihinsel engelli çocukların okuma becerilerine ses bilgisel farkındalık becerileri eğitiminin etkisinin incelenemesi. Yüksek Lisans Tezi. Hacettepe Üniversitesi Sağlık Bilimleri Enstitüsü, Ankara.

Güldenoğlu, B., Kargın, T. \& Ergül, C. (2016). Ses bilgisi farkındalık becerilerinin okuma ve okuduğunu anlama üzerindeki etkisi: boylamsal bir araştırma. Ilköğretim Online, 15(1).

Güneş, F. (2014) Türkçe öğretimi yaklaşımlar ve modeller. Ankara: PegemA.

Hempenstall, K. (1997) The role of phonemic awareness in beginning reading: A Review:1-32. 15.08.2015 tarihinde https://www.researchgate.net/profile/Kerry Hempenstall/ publication/287116492_The_Role_of_Phonemic_Awareness_in_Beginning_Reading_A_Revie w/links/56d9697708aebabdb40f7003/The-Role-of-Phonemic-Awareness-in-BeginningReading-A-Review adresinden alınmıştır.

Israel, S. E. (2008). Early reading first and beyond: A guide to building early literacy skills. California: Corwin.

İslamoğlu Külte, Ş. (2019). 2-6 yaş arası down sendromlu bireyler ile normal gelişim gösteren bireylerin fonolojik farkındalık düzeylerinin karşılaştırılması. Yüksek Lisans Tezi. Necmettin Erbakan Üniversitesi Eğitim Bilimleri Enstitüsü, Konya.

Justice, L. M., ve Ezell, H. K. (2001). Word and print awareness in 4-year-old children. Child Language Teaching and Therapy, 17(3), 207-225.

Kaminski, R. A., ve Good, R. H. (1998). Assessing early literacy skills in a Problem Solving model: Dynamic Indicators of Early Literacy Skills. M. R In Shinn (Ed.) Advanced applications of Curriculum Based Measurement. Guilford school practitioner series. New York: The Guilford.

Karakelle, S. (2004). Fonolojik farkındalık ve harf bilgisinin ilkokuma becerisi üzerindeki etkisi. Psikoloji Araştırmaları Dergisi,24, 45-56.

Karaman, G. (2006). Anasınıfına devam eden farklı sosyo-kültürel seviyedeki çocukların fonolojik duyarlııklarının incelenmesi. Yüksek Lisans Tezi. Anakara Üniversitesi Eğitim Bilimleri Enstitüsü, Ankara.

Kargın, T., Ergül, C., Büyüköztürk, Ş., \& Güldenoğlu, B. (2015). Anasınıfı çocuklarına yönelik Erken Okuryazarlık Testi (EROT) geliştirme araştırması. Ankara Üniversitesi Eğitim Bilimleri Fakültesi Özel Eğitim Dergisi, 16(03), 237-268.

Katz, J., Onen, F., Demir, N., Uzlukaya, A., \& Uludağ, P. (1974), A Turkish peabody picture vocabulary test. Hacettepe Sosyal ve Beşerî Bilimler Dergisi, 6, (1-2), 129 - 140.

Kazanoğlu, D. (2017). Türkçe fonolojik farkındalık testi geliştirilmesi, geçerlik, güvenirlik çalışması. Doktora Tezi. Anadolu Üniversitesi Sağlık Bilimleri Enstitüsü, Eskişehir.

Kılıç, S. (2015). Kappa test. Journal of Mood Disorders, 5(3), 142. 
Kleeck, A. V. (2008). Providing preschool foundations for later reading comprehension: The importance of and ideas for targeting inferencing in storybook-sharing interventions. Psychology in the Schools, 45(7), 627-643.

Kolinsky, R., Cary, L., \& Morais, J. (1987). Awareness of words as phonological entities: The role of literacy. Applied Psycholinguistics, 8(3), 223-232.

Konza, D. (2014). Teaching reading: Why the "Fab Five" should be the "Big Six". Australian Journal of Teacher Education, 39(12), 153. 15.08.2015 tarihinde https://files.eric.ed.gov/fulltext/EJ1047077.pdf adresinden alınmıştır.

Kozminsky, L., ve Kozminsky, E. (1995). The effects of early phonological awareness training on reading success. Learning and Instruction, 5(3), 187-201.

Lonigan, C. J. (2007). Vocabulary development and the development of phonological awareness skills in preschool children. InR. W. Wagner, A. E. Muse, \& K. R. Tannenbaum (Ed.), Vocabulary acquisition: Implications for reading comprehension (pp. 15 - 31). New York: Guilford Press.

Morris, D. (1993). The relationship between beginning readers' concept of word in text and phoneme awareness in learning to read: A longitudinal study. Research in the Teaching of English, 27, 133-154.

Özalp, B. (2011). Ilköğretim 1. ve 2. sınıf Türkçe ders kitaplarındaki metinlerin kelime sayısının kişisel kelime servetine katkııının değerlendirilmesi. Doktora Tezi, Selçuk Üniversitesi Eğitim Bilimleri Enstitüsü, Konya.

Özbay, M. ve Melanlıoğlu, D. (2008). Türkçe eğitiminde kelime hazinesinin önemi. Yüzüncü Yıl Üniversitesi Eğitim Fakültesi Dergisi,5 (1), 30-45.

Pallant, J. (2007). SPSS survival manual. New York, NY: Mc Graw Hill.

Parpucu, N. (2016). Seslerin Renkli Dünyası Programının okul öncesi çocukların fonolojik farkındalık becerileri üzerindeki etkisi. Yüksek Lisans Tezi, Anadolu Üniversitesi Eğitim Bilimleri Enstitüsü, Eskişehir.

Phillips, B. M., Clancy-Menchetti, J., \& Lonigan, C. J. (2008). Successful phonological awareness instruction with preschool children: Lessons from the classroom. Topics in Early Childhood Special Education.

Pullen, P. C., ve Justice, L. M. (2003). Enhancing phonological awareness, print awareness, and oral language skills in preschool children. Intervention in school and clinic, 39(2), 87-98.

Rathvon, N. (2004). Early reading assessment: A practitioner's handbook. Guilford Press.

Rief, S. ve Stern, J. (2010). The dyslexia checklist: a practical referance for parents and teachers. JosseyBass a Wiley Imprint San Francisco.

Sarı, B. (2012). Erken Çocukluk Dönemi Fonolojik Duyarlıık Ölçeği (EÇDFDÖ)'nin Geçerlik, Güvenirlik ve Norm Araştırması. Yüksek Lisans Tezi, Çanakkale Onsekiz Mart Üniversitesi Eğitim Bilimleri Enstitüsü, Çanakkale.

Sayar, F., ve Turan, F. (2012). Okuma gelişiminde üst dil farkındalığı, sesbilgisel süreçler ve bellek süreçlerinin etkisi: Kısa süreli bellek ve çalışma belleği. Ankara Üniversitesi Eğitim Bilimleri Fakültesi Özel Eğitim Dergisi, 13(02), 49-67.

Sénéchal, M., Ouellette, G., \& Rodney, D. (2006). The misunderstood giant: On the predictive role of early vocabulary to future reading. Handbook of early literacy research, 2, 173-182.

Silverman, R. D.(2007). A comparison of three methods of vocabulary instruction during read-alouds in kindergarten. The Elementary School Journal, 108(2), 97-113.

Soğancı, S. (2017). Sesbilgisel farkındalık becerilerinin sözcük okuma becerisi ile ilişkisinin incelenmesi: boylamsal bir çalışma. Yüksek Lisans Tezi, Ankara Üniversitesi Eğitim Bilimleri Enstitüsü, Ankara.

Sulzby, E., ve Teale, W. (1991). Emergent literacy. Handbook of reading research, 2, 727-757.

Sürgen, D. (2019). Öğrenme güçlüğü olan ve olmayan öğrencilerin fonolojik farkındalık, hızlı-otomatik isimlendirme ve çalışma belleği performanslarının incelenmesi. Yüksek Lisans Tezi, İstanbul Üniversitesi Lisansüstü Eğitim Enstitüsü, İstanbul. 
Şimşek, Ö. (2011). 60-72 aylık çocukların yazı farkındalığı ve yazmaya hazırık becerilerinin gelişiminde okuma yazmaya hazırlık programının etkisinin incelenmesi. Doktora Tezi, Gazi Üniversitesi Eğitim Bilimleri Enstitüsü, Ankara.

Taşkın, N., Sak, R., \& Sak, İ. T. Ş. (2015). Okul öncesi dönemde okuma yazma öğretimi: öğretmen görüşleri. Hacettepe University Faculty of Health Sciences Journal, 1.

Tavşancıl, E. (2010). Tutumları ölçülmesi ve spss ile veri analizi. Ankara: Nobel.

Topalca, S. (2019). Drama yönteminin dislekside sesbilgisel farkındalık becerisine etkisi. Yüksek Lisans Tezi, Gazi Üniversitesi Eğitim Bilimleri Enstitüsü, Ankara.

Torgesen, J. K. ve Mathes, P. G. (2002). Assessment and instruction in phonological awareness. 15.08.2015 tarihinde https://files.eric.ed.gov/fulltext/ED473732.pdf adresinden alınmıștır.

Torgesen, J. K., ve Mathes, P. G. (1998). What every teacher should know about phonological awareness. Florida Department of Education, Division of Schools and Community Education, Bureau of Instructional Support and Community Services.

Turan, F, ve Akoğlu, G. (2011). Okul öncesi dönemde ses bilgisi farkındalık eğitimi. Eğitim ve Bilim, 36(161).

Turan, F. ve Akoğlu, G. (2014). Okul öncesi dönemde ev okuryazarlık ortamı ve fonolojik farkındalık becerileri. Hacettepe Üniversitesi Eğitim Fakültesi Dergisi, 29(3), 153-166.

Turan, F. ve Gül, G. (2008). Early precursor of reading: acquisition of phonological awareness skills. Educational Sciences: Theory ve Practice, 8(1), 279-284.

Walley, A. C., Metsala, J. L., \& Garlock, V. M. (2003). Spoken vocabulary growth: Its role in the development of phoneme awareness and early reading ability. Reading and Writing, 16(1-2), 5-20.

Weir, B. (1989). A Research Base for Pre-kindergarten Literacy Programs. The Reading Teacher 42 (7), 456-460.

Yücel, D. (2009). Ses bilgisi farkındalık (fonolojik farkındalık) eğitiminin okuma sorunu olan çocuklar üzerindeki etkisinin incelenmesi. Yüksek Lisans Tezi, Hacettepe Üniversitesi Sağlık Bilimleri Enstitüsü, Ankara.

\section{Introduction}

\section{Extended Abstract}

In alphabetical written languages like Turkish, words are transferred to writings at phoneme level. In Turkish, there is one-to-one relationship between the sound and letter. In languages like Turkish with transparent relationships between sound-letter, phonological awareness skill should be acquired to learn how the words are represented in written. Therefore, training programs should be prepared to improve phonetic awareness skills appropriate for language structure of Turkish.

Early literacy skills develop in early childhood period not in series, but in together and interactive fashion. Therefore, the training programs prepared for phonological awareness are not expected solely to improve phonological awareness skills. In Turkey, number of studies inquiring the effects training programs prepared for phonological awareness skills on early literacy skills is quite limited and available ones mostly focused on pre-school (Bayraktar, 2013) and specially-trained students (Akoğlu and Turan, 2012; Gül, 2006). Effects of phonological awareness skills on reading skills continue not only in pre-school period, but also in upper classes (Chard and Dickson, 1999). Since cognitive-linguistic skills of the kids start to mature at the age of six and they start to learn how to read alphabetic writings, it is quite significant to develop phonetic awareness skills at the first grade (Bentin, Hammer and Cahan, 1991: 271).

In this study, a training program was prepared to acquire and develop phonological awareness skills of normally-progressed first grade primary school students and the effects of this program on early literacy skills (phonological awareness, print awareness and vocabulary knowledge) were investigated. 


\section{Method}

Phonological awareness, print awareness skills, vocabulary knowledge and alphabet knowledge of experimental and control-group students were measured before and after the experimental process. Phonological Awareness Program (PAP) composed of seven stages ("listening rhyme - word - syllable - onset-rime - phoneme - sound - letter matching") was applied to experimental group students in 40 session for eight weeks, five days a week. Dependent groups (paired) t-test and Wilcoxon singed rank test were applied to assess the significance differences between pre-test and post-test scores of experimental and control group students; independent groups (unpaired) t-test and Mann-Whitney $U$ (MWU) test were used to assess the significance of the differences between the post-test scores of experimental and control group students. Effect size values were determined to see the level of difference between post-test scores. Significance level was considered as ",05".

\section{Result and Discussion}

Phonological awareness skills contribute especially to phonemic awareness, decoding sound characteristics of the told word, development of alphabetical principles required for comprehension of written words. Therefore, phonological awareness with the effects on decoding abilities of the children phonologically within the text has the primary effect on development of reading skills (Torgesen and Mathes, 1998: 4). Phonological awareness could be developed with the trainings provided (Aktan Kerem, 2001; Bayraktar, 2013; Kozminsky and Kozminsky, 1995; Turan and Akoğlu, 2011). Present findings revealed that the present phonological awareness training provided within the scope of PAP developed phonological awareness skills of the first-grade students.

Print awareness provide contributions in acquisition of reading skills and settled with the acquisition of reading. Bay, Altun and Çetin (2014: 255) indicated print awareness as among the most powerful skills designating future reading ability of the children. According to some researchers, characteristics of a written language are required for development of word awareness phonologically (Kolinsky, Cary and Morais, 1987: 223); separate hearing of sounds and words of a written language is required for development of letter and word awareness in written language (Bayraktar, 2013: 60). Print awareness skills could be developed with the trainings provided (Bayraktar, 2013; Şimşek, 2011). According to present findings, it was observed that the present phonological awareness training provided within the scope of PAP developed print awareness skills of the first-grade students.

Oral language and vocabulary knowledge influence greatly not only the speech skills, but also reading and writing skills (Beauchat, Blamey and Walpole, 2010: 17). Although oral language does not directly support the development of decoding skills, it constitutes a potential source for development of phonological awareness (Lonigan, 2007: 21-22). Word utilization and comprehension levels of the children could be improved word learning activities and rich learning programs (Beck and Mckeown, 2007; Silverman, 2007). According to present findings, it was observed that the present phonological awareness training provided within the scope of PAP developed word knowledge levels of the firstgrade students. 